\title{
ethic@

\author{
A TEORIA DE DEUS E O DESAFIO DO NIILISMO: HANS JONAS \\ A PROPÓSITO DE NIETZSCHE
}

\author{
THE THEORY OF GOD AND THE CHALLENGE OF NIILISM: HANS \\ JONAS ABOUT NIETZSCHE
}

JELSON ROBERTO OLIVEIRA ${ }^{\mathbf{1}}$

(PUCPR, Brasil)

\begin{abstract}
RESUMO
Pretende-se, nesse artigo, analisar a interpretação de Hans Jonas do aforismo 125 de A Gaia Ciência, de Nietzsche, tal como ela se apresenta na reflexão desenvolvida nas aulas ministradas por Jonas no Carleton College, de Ottawa, no semestre de inverno de 1952-1953 e guardadas nas anotações (inéditas) intituladas The theory of God, conservadas no Philosophisches Archiv de Hans Jonas, na Universität Konstanz. Para tanto, partimos da análise jonasiana do medo do desconhecido como elemento central nas filosofias de Epicuro e, especialmente, Pascal, para mostrar como Nietzsche aprofunda a reflexão iniciada pelo filósofo de Port-Royal e como a intensificação do medo e do sentimento de solidão se apresentariam como possibilidade de enfrentamento do niilismo. Do ponto de vista dos interesses próprios de Jonas, não só estaríamos diante de uma teoria sobre Deus, em sentido estrito, mas de uma reflexão sobre a tecnologia como "vontade de ilimitado poder", ou seja, como exercício do homem que, sozinho e sem Deus, busca o domínio sobre o mundo.
\end{abstract}

Palavras-chave: niilismo; morte de Deus; Hans Jonas; Nietzsche.

\begin{abstract}
In this article, we intend to analyze Hans Jonas's interpretation of Nietzsche's section 125 of The Gay Science, as it is presented in the reflection developed in the lectures taught by Jonas at Carleton College, Ottawa, during the winter semester of 1952-1953 and kept in the (unpublished) notes entitled The Theory of God, preserved in the Philosophisches Archiv Hans Jonas, at the Universität Konstanz. For this, we start with the Jonasian analysis of the fear of the unknown as a central element in the philosophies of Epicurus and especially Pascal, to show how Nietzsche deepens the reflection begun by the philosopher of PortRoyal and how the intensification of fear and feeling of loneliness would present itselves as a possibility of confronting nihilism. From the point of view of Jonah's own interests, we would not only be dealing with a theory about God in the strict sense, but a reflection on technology as "the will of unlimited power", i. e., as the exercise of man who, alone and without God, seeks dominion over the world.
\end{abstract}

Keywords: nihilism; Death of God; Hans Jonas; Nietzsche.

\section{Introdução}

Embora Hans Jonas não tenha se dedicado a um estudo específico da filosofia de Nietzsche, as referências ao autor de Assim Falou Zaratustra são frequentes em seus 
trabalhos, principalmente no que diz respeito ao tema do niilismo, que nós consideramos um dos eixos centrais da obra jonasiana, tanto do ponto de vista de seu diagnóstico (que articula os estudos sobre o gnosticismo em sua relação com o existencialismo contemporâneo) quanto em seu enfrentamento (na perspectiva da formulação de uma nova ontologia da vida, da qual deriva uma nova antropologia e uma ética da responsabilidade). Entre os vários textos de Hans Jonas sobre o assunto, destaca-se o manuscrito inédito intitulado The Theory of God, no qual o autor analisa a afirmação nietzschiana "Deus morreu", tal como ela aparece no fragmento 125 de A Gaia Ciência, obra publicada em 1882. Uma parte dos textos que formam esse manuscrito, guardado nos Philosophisches Archiv de Hans Jonas, na Universität Konstanz, é formada por anotações das aulas feitas por Jay MacPherson e posteriormente revisadas e completadas por Hans Jonas. O curso de Jonas foi proferido no Carleton College, em Ottawa, Canadá, no semestre de inverno de 1952-53.

$\mathrm{O}$ interesse de Jonas nesse curso foi o de realizar uma interpretação do modo como o conceito de Deus foi tematizado pela tradição filosófica a partir da ideia de medo (fear). Para tanto, ele parte de uma análise do problema tal como ele se apresenta na filosofia de Epicuro e Lucrécio, passando por Hobbes, Hume, Pascal e, finalmente, Nietzsche, com referências também a Aristóteles, São Paulo e Santo Agostinho. Nesse texto, tentaremos retomar, rapidamente, os argumentos de Jonas a respeito da filosofia de Epicuro para, então, analisar como ele compreende o lugar ocupado por Pascal e, posteriormente, por Nietzsche, como precursores da teoria moderna sobre Deus. Trata-se de demonstrar como, para Jonas, Epicuro viu a necessidade de superação da religião como requisito para a superação do medo (e, consequentemente, para o alcance da vida feliz) e como Nietzsche, ao mesmo tempo em que se insere nessa tradição, radicaliza suas consequências ao afirmar, pela via do niilismo, que a morte de Deus, antes de representar uma solução para o medo, leva ao seu aprofundamento - e essa é a condição básica para o enfrentamento do niilismo: desvencilhar-se das falsas seguranças trazidas pela religião.

\section{A solidão do homem diante da morte de Deus}

Jonas identifica os sentimentos de solidão como próprio da condição espiritual do homem contemporâneo, marcada pelo niilismo. Tal sentimento, associado ao medo, teria sido descrito de forma exemplar pelo existencialismo, mas suas bases estariam já nos movimentos gnósticos da Antiguidade (aos quais Jonas se dedica ao longo de toda a sua vida ${ }^{2}$, na perspectiva de caracterizar o que poderíamos chamar de uma "tipologia existencial" ou de um "princípio gnóstico" [RG, $61]^{3}$ ) e que estaria ligado à própria crise da razão, que faz o homem trocar o seu antigo orgulho diante da natureza pela angústia de sua própria condição, o que levou à crise da sua própria "imagem" na forma do antiessencialismo que marca as filosofias contemporâneas. Essa é, 
segundo Jonas, a posição paradoxal da vida ética moderna captada pelo existencialismo, interpretado por ele como uma expressão máxima de uma antropologia que resultou do dualismo, que percorre a cultura ocidental como uma de suas marcas mais preponderantes: de um lado, "o valor e a obrigação são conferidas [ou criadas] pelo homem e não descobertas"; e de outro, "toda a natureza não humana é desprovida de valor e de fim, e não implica nenhuma obrigação" em relação ao mundo no qual está inserida (FROGNEUX, 2001, p. 64). O resultado é um afastamento do homem em relação ao mundo na forma de uma desobrigação e uma irresponsabilidade, representadas pela reivindicação de uma liberdade absoluta que encontra nos poderes da tecnologia a sua expressão mais acabada: tratar-se-ia de uma "vontade de ilimitado poder" (TME, 34) do homem que, sozinho e entediado, entretém-se com o mundo transformando-o em um grande campo de exploração, disponível para seu domínio e para o exercício (sem finalidade) de suas próprias forças. Como consequência, o pensamento moderno recupera o antinomismo do gnosticismo: o mundo, neutro e objetivo, desprovido de valor a não ser aquele que o sujeito the impõe, impede a passagem do ser para o dever ser.

No seu diagnóstico sobre as consequências do modo de relação que a modernidade estabeleceu entre homem e divindade, Jonas está atento à diferença cabal entre as posições de Pascal e de Nietzsche: para o primeiro, o universo é criado por um Deus transmundano ao qual o homem solitário ainda pode elevar o seu coração; para o segundo, Deus é apenas uma invenção inventada como remédio que, ao invés de curar, apenas impede que o homem se coloque diante de si mesmo, ou seja, que tome consciência de sua própria solidão. O Deus pascaliano, portanto, é um Deus desconhecido, um ágnostos theós, que não é discernível no ambiente de sua criação: "o universo não revela o propósito do criador por meio do modelo de sua ordem, tampouco revela sua bondade por meio da abundância das coisas criadas, nem sua perfeição pela beleza do conjunto; o universo só revela seu poder por meio de sua magnitude, de sua imensidão espacial e temporal" (RG, 341). Para Jonas, a única coisa que o mundo tem ainda que o aproxima, em Pascal, da divindade, é a magnitude e, segundo ele, "o que a magnitude pode comunicar é poder" (RG, 341), ou seja, o mundo estaria reduzido à manifestação de um poder que se apresenta em sua magnitude. Dessa forma, segundo Jonas, para Pascal, ainda restaria a pergunta sobre o porque a vontade divina trouxe o homem "a este remoto rincão da natureza". O deus absconditus deixaria, assim, também o homo absconditus, marcado simplesmente pela vontade e pelo poder, "a vontade para conseguir o poder, a vontade de vontade" (RG, 341) para a qual a natureza se apresenta apenas como uma oportunidade de exercício. Nesse sentido, o gnosticismo persistente na filosofia heideggeriana seria ainda mais evidente quando pensado sob a perspectiva da divindade, já que, se a gnose (mesmo em seus resquícios pascalianos) ainda tinha uma referência divina, com o diagnóstico nietzschiano da morte de Deus, também o existencialismo e, nele, a filosofia heideggeriana, perderam essa perspectiva e, com ela, qualquer referência a auto-redenção. $O$ 
homem, nesse caso, resta entregue à indiferença da natureza e às suas próprias forças diante do mundo da morte.

Ora, se no gnosticismo a estranheza e o estrangeirismo da divindade a tornavam inalcançável, no mundo contemporâneo essa inacessibilidade é radicalizada pela ideia nietzschiana da morte de Deus. Morto, Deus deixa o homem sozinho no mundo, sem esperança de salvação, sem nenhuma meta ou sentido da existência, sem qualquer perspectiva de superação da sua própria condição a não ser expor-se ao mundo como campo de exercício de suas forças. No mundo sem Deus, o homem vive a sua orfandade radical, como experiência do vazio. Se o homem é o ser que inventou a si mesmo ao tentar dizer não à natureza, com a morte de Deus ele se sente amedrontado e sozinho. Em Pascal, esse medo se revela como crescente assombro; em Nietzsche, como busca pelo remédio ilusório oferecido pela religião; em Jonas, finalmente, na esteira de sua interpretação de Nietzsche, como uma entrega ao exercício da vontade de poder, que se revela como vontade técnica. Nessa última perspectiva, o homem tenta se reinventar dizendo não à divindade ou, melhor ainda, perante o não que a divindade se tornou (porque Deus tem "mais de nihil do que de ens em seu conceito" [RG, 349], afirma Jonas). Diante desse fato, resta a ele buscar uma nova relação com o mundo, embora não uma relação de concordância. Como tentativa de transcender a sua solidão existencial, o homem experimenta o poder de domínio sobre o planeta desligando-se do ambiente em que se situa para melhor explorá-lo. Estamos na época da ação, da entrega total ao trabalho (conforme apontara Jünger), a época de Sísifo e seu trabalho sem fim (como escreveu Camus), um modo de trabalhar que corresponde à vida sem finalidade da sociedade moderna, para quem a solidão tem um duplo significado: uma ruptura com o mundo e uma tentativa de criar outro, que faz dos solitários, trabalhadores da técnica e desses, heróis e redentores.

\section{O medo do desconhecido}

Essa questão é aprofundada por Jonas em Theory of God (HJ, 20-2-1). Para ele, Epicuro teria sido o primeiro e o único autor grego a propor, por meio da filosofia, "liberar o homem do apelo religioso", o que significava dar ao homem o poder de se livrar "de um certo tipo de escravidão da qual a religião era o principal símbolo e expressão" (HJ, 20-2-1), uma escravidão que, afinal, era "expressa pelo medo". Nesse contexto, caberia à filosofia demonstrar, por meio do conhecimento, como esse era um sentimento infundado. Dois temores impediam, segundo Epicuro, que o homem alcançasse a felicidade, o medo dos deuses e o medo da morte e eles deveriam ser enfrentados com a reflexão filosófica: "não pode afastar o temor que importa para aquilo a que damos maior importância quem não saiba qual é a natureza do universo e tenha a preocupação das fábulas míticas. Por isso não se podem gozar prazeres puros sem a ciência da 
natureza" (EPICURO, 1985, p. 50). Para Jonas, "o homem é dominado pelo medo, acima de tudo pelo medo da morte, embora esse seja apenas outra variante do medo do desconhecido" que está presente no medo dos deuses. Isso significa que o "medo do desconhecido", que "é o maior de todos [os medos], que não pode ser medido e diante do qual nenhuma provisão pode ser feita" constitui-se como um aspecto central da condição do homem. Seguindo a estratégia epicurista, Jonas se pergunta sobre "qual é a natureza do medo" e aventa duas hipóteses:

1. Mesmo a dinâmica das coisas mais familiares para nós, isto é, a falta de conhecimento sobre a natureza, transforma-se em algo mistificado e terrificado se não for entendido.

2. A realidade não conhecível, isto é, que chega depois da morte. O medo da morte é o medo de algo que está do outro lado de nossa experiência onde um espaço igualmente ilimitado torna possível para nossa imaginação colocar todos os acontecimentos possíveis. (HJ, 20-2-1)

Não conhecer, por isso, é o motivo do medo e ele se revela tanto como um medo do deus estranho no gnosticismo, quanto como um silêncio do universo (no pensamento pascaliano) ou mesmo como um sentimento de total ausência de sentido (presente no niilismo moderno). Para Jonas, por isso, o medo da morte na verdade é parte desse medo do desconhecido que está além da vida e que se revela como "medo da punição [e dos] julgamentos que esperam a nossa alma" (HJ, 20-2-1) do outro lado; ora, é precisamente esse o tipo de libertação proposto por Epicuro: livrar-se da ansiedade trazida por esse tipo de medo das coisas estranhas que possam acontecer conosco depois da morte. Se, como propõe o filósofo grego, não há esse "depois", então não haveria mais razão para que o medo existisse e essa seria a principal consolação trazida por esse tipo de filosofia que se contrapõe à fé. Dizer que não há nada de eterno é o modo como o homem se livra do "veneno" do medo, embora esse tipo de consolação exija uma "mente brava e corajosa", porque ela requer não apenas a anulação da ideia de um "depois", mas o reconhecimento de que o "agora" está destinado a passar, que a alma morre com o corpo e que tudo está submetido à temporalidade. Para Jonas, a filosofia de Epicuro (ademais, diferentemente da de Spinoza) demonstra como a ignorância é o terreno fértil par ao crescimento do medo, porque ela seduz o homem para as causas imaginárias e para as entidades criadas para sanar as faltas do conhecimento ("stop-gaps of our knowledge") e, ao mesmo tempo, incorpora e cresce no homem por meio de seus medos. Ou seja: quanto mais ignorância, mais medo; quanto mais medo, mais ignorância. Por isso, a filosofia epicurista empenhou-se tanto em "ensinar as verdadeiras causas para que mente do homem seja liberada de seus mais terríveis inimigos, seus próprios medos" (HJ, 20-2-1). Ora, já que os medos estão incorporados nos deuses, então eliminar os medos significa também eliminar os deuses; e vice-versa: eliminar os deuses (ou a religião) é o caminho principal para a superação dos medos, na medida em que a religião é, ao mesmo tempo, "ignorância e medo imaginativo". Para Jonas, a filosofia de Epicuro se baseia, assim, na mesma 
perspectiva socrática que escolheu o conhecimento como realização da natureza plena do ser humano e como caminho para retirá-lo da escuridão, abrindo caminho para uma compreensão adequada da "natureza das coisas", ou seja, para uma visão coerente da natureza. Mas isso sem que Epicuro fosse, necessariamente, um ateísta: para Jonas, o que ele propõe estaria próximo da atitude moderna de uma "religião sem Deus".

Para Jonas, Pascal é uma espécie de ponte de reconciliação entre o homem e seus medos: "ele está assustado (haunted) pela ideia dos espaços vazios e isso influencia todo seu pensamento, o qual é muito pessimista, provavelmente devido ao fato de que ele esteve mal de saúde a maior parte de sua vida" (HJ, 20-2-1). Jonas se refere à preocupação pascaliana em relação ao silêncio dos espaços infinitos que ignoram a situação humana e que, por isso, lhe aterrorizam, revelando o medo do homem moderno diante do desconhecido, que se revelaria em dois tipos de infinitos, tanto no macro quanto no microcosmos: "o nada do qual ele é feito e o infinito no qual ele está submergido..." ou seja, "o homem é o meio entre o nada e o tudo" e a ele cabe caminhar entre esses dois abismos que nele se encontram como que amarrados. Essa situação faz com que o homem esteja sempre perdido, procurando um lugar para si mesmo: “ele está sempre procurando por um lugar no universo hostil", afirma Jonas. Mas para Pascal é justamente essa procura, a consciência da própria ignorância e do próprio medo, que abririam a possibilidade de uma redenção. Ao contrário de Epicuro, que condena o medo, Pascal evocaria a possibilidade de que justamente o desespero possa conduzir o homem até a salvação, ou seja, até Deus: "o medo para Pascal não é medo da punição no inferno, mas medo de estar sozinho no vazio separado de Deus", ou seja, "o verdadeiro tormento é estar separado de Deus" (HJ, 20-2-1). O problema é que o mundo, em si mesmo, nos distancia de Deus e nisso reside, para Pascal, a mensagem de Cristo, aquele que nos salva de nossa miséria e abre um caminho até Deus. Jonas lembra que Pascal era jansenista, o que significa que para ele "a tarefa da alma caída longe de Deus era achar seu caminho de volta" e, para isso, ela deve compreender a sua situação de isolamento, ou seja, reconhecer e sentir o próprio medo. O medo aparece, então, como um “estágio necessário", uma experiência de terror diante do espaço e face à distância entre homem e Deus.

Ao contrário do que acontece em Hobbes (para quem, segundo Jonas, o medo tem uma interpretação "naturalística", ligada à necessidade de superar a situação precária do homem em sua vida isolada), em Pascal o medo tem um aspecto "espiritualístico", embora ambos não acreditem que alguma pretensa "salvação do homem" encontre-se em sua própria natureza. Como elemento espiritual, o medo é, para Pascal, um sentimento de estranheza diante da infinidade não conhecida, uma espécie de pânico diante da compreensão da imensidão cósmica e a "consciência das coisas muito pequenas da natureza cujo sentido e natureza o homem não pode penetrar". Isso tornaria Pascal, "um dos precursores da psicologia profunda (depth psychology) que vê quantas infinidades existem dentro da mente do homem para serem abertas" e mesmo um disseminador 
da ideia moderna de subjetividade: "o sujeito agora tem todo o mundo diante dele: o homem e a natureza que se lhe opõe". Reconhecendo que o homem é, ele mesmo, um abismo (abyss), Pascal se ligaria a um tema que, segundo Jonas, é próprio da tradição que remete a São Paulo e Agostinho (principalmente no décimo livro das Confissões), embora não à tradição grega clássica, na qual o termo sequer aparece. Isso significa que, ao contrário do que ocorria entre os gregos (Epicuro e Lucrécio são os exemplos analisados por Jonas nesse texto), Pascal não acredita que o homem pode alcançar um conhecimento de si capaz de salvá-lo do medo. Ao contrário, quanto mais reconhece o abismo de si mesmo, mais o homem sente-se amedrontado.

Em Pascal, por isso, o autoconhecimento não é um repouso diante do medo. Se no caso dos gregos, tratava-se de superar o medo (o que significava superar a religião que se fundava sobre ele) por meio de uma relação racional com a natureza e com o divino, no caso de Pascal, deus está continuamente escondido e qualquer coisa que possa ser dito sobre ele será reduzida à perspectiva humana, ou seja, com Pascal estamos "no campo da visão antropológica da religião". Sendo um "artigo" do homem, Deus, como "objeto" em si mesmo, não é mais do que um desconhecido, o que acabaria por aumentar a carga de desespero humano por não poder reconhecê-lo. Mesmo porque, na modernidade, o cosmos não oferece nenhuma possibilidade de compreensão desse Deus, já que o mundo não é mais feito "à sua imagem”, ou seja, "não partilha a sua divindade", agora substituída pela aparição moderna de termos como "natureza sem vida" ou "natureza inanimada".

\section{Matar Deus para livrar-se do medo}

Assim, diante da natureza, da qual se diferencia e se estranha, o homem não vê outra alternativa senão tornar-se o "fazedor" (maker), ou seja, ele "sujeita a natureza à sua própria compreensão (insight), a natureza se torna uma coisa para ele". Como maker, o homem pode refazer o mundo, porque ele não está submetido a nenhuma regra exterior e, assim, desdivinizado, o mundo não é governado "por nenhuma perfeição intrínseca" e, ainda mais, não contém nenhuma hierarquia entre o que poderia ser considerado mais ou menos nobre, por exemplo. Já nesse texto, de 1952, Jonas liga essa questão à tecnologia, reconhecendo: "há certa relação entre tecnologia e a relação [do homem] com a natureza" (HJ, 20-2-1): como fazedor, o homem exerce sua vontade de poder sobre a natureza por meio da expansão de seu domínio tecnológico porque ele encontrase sozinho e sem qualquer impedimento de ordem natural: "ele está sozinho com seu próprio destino no mundo" e, assim, segundo Jonas, "ele descobre que ele não é somente o potencial criador de um outro mundo, mas também o potencial e necessário criador de seu próprio ser". Sua plena liberdade, nesse caso, é também uma ausência de orientação (guidance). Sozinho, o homem deve tomar o seu destino em suas mãos ou, sob "sole motto [em uma palavra] a vontade de poder. 
E isso é Nietzsche e sua posição", escreve Jonas. Dessa forma, o total desimpedimento do homem "é o desimpedimento do niilismo" com o qual ele se torna mais corajoso para enfrentar o mundo desconhecido que se abre à sua frente, mas ao mesmo tempo, afirma Jonas, isso não significa que ele é menos desesperado. Ao contrário, ao que parece, a situação do niilismo antropológico é agravada pela experiência de ter de fazer (criar ou re-criar) o mundo, embora sem que esse fazer se apresente como solução para o desespero e o vazio próprios do niilismo. $\mathrm{O}$ trabalho técnico acaba por não preencher jamais o vazio do niilismo, senão com mais vazio.

Ao analisar a posição de Nietzsche, Jonas afirma que ela também se apresenta em sentido diferente daquela de Epicuro e Lucrécio, na medida em que o autor de A gaia ciência "não [acredita] que a religião é a coisa mais temível e que estar livre da crença nos deuses é ser livre do medo, mas que a religião e a crença nesses poderes é uma espécie de câmara protetora para o homem e que recuar alguns degraus quanto a isso é descer até a mais temível situação" (HJ, 202-1). A religião seria, assim, para Nietzsche, uma espécie de consolo diante do medo e de abstenção diante da verdadeira angústia da sua solidão, porque a crença exerceria o papel de tranquilizante, como facilmente se pode encontrar em diferentes livros de Nietzsche, especialmente em Aurora, Além de bem e mal e Para a genealogia da moral. Isso quer dizer que, para Nietzsche, não se trata de emancipar do "medo causado pela crença nos deuses", mas "da segurança da religião diante do medo do nada". Se a religião é uma espécie de mecanismo protetor diante do niilismo, livrar-se dela é necessário para abrir-se ao sentimento de solidão que é próprio do homem. Ora, nesse novo estágio de emancipação, não só o homem se encontra sem a referência a qualquer norma absoluta, como também ele se acha como o único criador de leis e, consequentemente, passa a entender que todas as leis carecem de qualquer validade absoluta: para Jonas, Nietzsche "sente que o homem deve tomar seu lugar e criar suas próprias tábuas de valor, suas próprias leis; e que essas leis emanam somente dele e não de Deus e, mais, que ele não pode atribuir absoluta validade a nenhuma lei". Isso significa, consequentemente, que "a lei deve ser imposta pelo poder e pela força", ou seja, por meio da vontade de poder, que se revela como um desdobramento do niilismo precisamente porque ela é um produto do sentimento de solidão e da necessidade de emancipação do homem. Por isso, para Jonas, Nietzsche não propõe uma "emancipação dos deuses para a liberdade, como em Epicuro, mas uma emancipação para o medo e a solidão", como medidas de dissolução das crenças que ofereciam falsas seguranças.

Seguindo a sua argumentação, Jonas cita e comenta o fragmento 125 de A Gaia ciência, que ele considera como uma "peça formidável", escrita por um autor que ele considera "o mais simbólico homem moderno, o antecipador da mente moderna que encontra expressão no existencialismo". Jonas reconhece que a morte de Deus é uma ideia antiga, pré-judaica e remete à representação dos ciclos da natureza (no caso dos gregos) ou mesmo à morte de todos os deuses (segundo certa tradição mítica germânica, na qual "o mundo inteiro dos deuses é condenado à 
morte final"). O jovem Nietzsche, lembra Jonas, conhecia essa história, por afirmar: "eu acredito nas antigas declarações germânicas - todos os deuses devem morrer" (HJ, 20-2-6). No mundo grego, a morte dos deuses é descrita como um ato violento, que inclui algum animal selvagem, forças brutais da natureza ou seres de natureza demoníaca. Sendo assim, lembra Jonas, "os deuses poderiam ser eternamente jovens, mas assassinados" e "seu renascimento é um milagre que requereria a intervenção de outros deuses"; o que Jonas quer mostrar é que "nas antigas religiões, Deus não morre de velhice, mas é assassinado" (HJ, 20-2-6) e é justamente isso que Nietzsche traz à tona: o homem é o assassino de Deus e esse é o seu ato de poder mais evidente - eis o sentido das três perguntas feitas pelo homem a si mesmo no aforismo 125 de A gaia ciência: "quem nos deu a esponja para apagar o horizonte", "como conseguimos beber inteiramente o mar", "quem desatou a terra de seu sol”. Nessa situação, o homem está sozinho diante do seu ato e, antes de estar arrependido ou de lamentar o seu feito, parece impressionado com seu próprio poder, com o ato de ter feito o que fez. Jonas interpreta, assim, a ideia de morte de Deus a partir de uma leitura histórica da tradição segundo a qual, de vez em quando é preciso reconhecer que "o tempo dos deuses terminou”. Como acontecera com os deuses olímpicos, que substituíram os seus antecessores, também agora "o assassinato de um deus ou do domínio dos deuses significa que o tempo para eles passou - não mais exigem a adoração do homem" (HJ, 20-2-6). O assassinato dos deuses é uma espécie de "revolução mitológica", compreendida por Jonas como a ascensão de um tipo de crença mais adequada aos novos tempos: é como se o assassinato dos deuses fosse necessário para o surgimento de "novas gerações de deuses mais adequados aos pensamentos e crenças dos homens", porque "novos deuses eram expressões da mudança no pensamento e na vida do homem". Nesse sentido, "de tão velhos, os deuses são depostos" (HJ, 20-2-6). Nietzsche, por isso, segundo Jonas, "fala na linguagem desses antigos mistérios" embora acrescente algo novo: o fato de que, agora, o homem seja o assassino de Deus e isso porque ele reconhece que tal divindade vive no homem. O autor de Assim Falou Zaratustra teria levado muito a sério a afirmação de que Deus é uma invenção humana: isso significa que foi essa ideia que deu condições para que "os homens vivessem como homens", ou seja, que eles se "levantassem acima das meras criaturas da natureza" e que eles tivessem a devida consciência sobre o fato de que Deus era uma projeção sua. Para Jonas, Nietzsche viu o benefício dessa ignorância como algo necessário para a sobrevivência do homem. A isso ele chamou cultura, ou seja, o horizonte fechado de suas próprias projeções, um espaço delimitado do conhecimento, além do qual estaria uma quantidade imensa de coisas desconhecidas, cuja ignorância é salutar para que o homem possa desenvolver a si mesmo. Jonas cita, a esse propósito, o texto de Nietzsche Sobre a vantagem e da desvantagem da história para a vida, na qual a ideia da ignorância e do esquecimento é tratado como algo positivo para a vida: "é preciso ter certa quantidade de cega (blindness) 'ilusão protetora' para que os homens acreditem em uma ideia para viver" (HJ, 20-2- 
6). Mas para que essa ideia seja eficaz em termos de crença, é preciso que os homens desconheçam as "pressuposições nas quais esta ideia se assenta" - e isso, para Jonas, "serve para a religião", na medida em que ela parte de certa ignorância dos motivos para tornar a vida humana suportável. E, ao contrário: "uma vez que saibamos do que a religião é feita, ela cessa de ser um apoio, uma força vital".

Para Jonas, o propósito central da filosofia de Nietzsche se resume no aforismo 125: "mostrar como o homem pode viver com seu conhecimento e sem Deus", ou seja, como o homem pode acessar o mundo pelas próprias forças (poderes) sem contar mais com o apoio de alguma entidade ilusória oferecida pela religião. Por isso, a religião é reconhecida como uma fase primordial e como um "fenômeno essencial" da história humana conta a qual, agora ele mesmo, Nietzsche, dirige a sua psicologia, como forma de compreensão das motivações segundo as quais a mente humana se tornou dependente dos alívios oferecidos pelos ideais religiosos. O pressuposto dessa interpretação seria justamente o fato de que Deus é uma construção inconsciente do homem, algo que, afinal, Nietzsche tematiza amplamente a partir de Humano, demasiado humano (principalmente no capítulo sobre $A$ vida religiosa) obra na qual ele toma a psicologia como instrumento de crítica à metafísica e fala da "necessidade metafísica" (HH, 26), e uma má-interpretação da dor e do sofrimento como derivações de um castigo divino que se abatera sobre o homem, seja por sua "interpretação falsa" $(\mathrm{HH}, 126)$ do homem a respeito de si mesmo ${ }^{4}$. Na sua leitura, Jonas reconhece Nietzsche como o "primeiro pensador ateu que é sincero e não superficial" sobre esse tema, ao contrário de Voltaire, por exemplo. Nietzsche não é otimista quanto ao seu diagnóstico: ele "não está contente com a liberdade alcançada pelo declínio da igreja ou da religião", mas, ao contrário, ele "vê que a humanidade deve passar por um período de niilismo - um período de aprofundamento do desespero" na medida em que se vê diante daquele que Nietzsche considera o maior crime já cometido pela humanidade: ter assassinado a Deus.

Para Jonas, utilizando-se da psicologia, Nietzsche tenta explicar porque o homem assumiu com tanto entusiasmo a ideia de Deus, uma ideia e uma doutrina que, afinal, o humilha tão profundamente, mas mesmo assim é aceita por ele com tanto fervor. Eis o paradoxo da religião cristã: "o homem abraça um sistema de valores que coloca de cabeça para baixo a origem de tais valores" ou seja, a ideia de que o bem nasce não da bondade, mas da força identificada com a hierarquia de classe, ou seja, com a aristocracia: "se ele sustenta que os valores são uma expressão da força e do poder, não da fraqueza, como então podemos levar em conta o fato de que triunfou finalmente um sistema de valores nos quais o orgulho é rebaixado e o caniço quebrado é elogiado?" (HJ, 20-2-6). A análise de Jonas caminha na direção da interpretação nietzschiana do ascetismo: primeiro, o de tipo platônico, segundo o qual o homem deveria negar (e ter sob controle da razão) os instintos corporais; segundo, o de tipo natural, segundo o qual a natureza como um todo seria marcada pelo pecado, pela impureza e pela corrupção, cabendo ao homem distanciar- 
se dela, ou seja, não apenas controlá-la, mas sobretudo "exterminá-la, matar os desejos da carne - ter medo de suas atrações". Nesse segundo caso, a mortificação da natureza é o objetivo central. A questão de Nietzsche seria mostrar como isso é possível, ou seja, como o homem passou a temer justamente aquilo que era mais forte e poderoso nele, ou seja, o seu próprio corpo; como o homem pôde viver sob o signo da abnegação de si mesmo, daquilo que era o melhor de si mesmo? Nietzsche busca a resposta do "outro lado", ou seja, na atitude de humildade, graça e expectativa da própria bondade - "aqui Nietzsche vê um problema real", porque ele parte de uma "espécie de axioma" segundo o qual "a vida é essencialmente vontade de poder e está sempre disposta a realizar a si mesma" e, nesse caso, como poderia o instinto de fraqueza ter se tornado tão "forte"? Seu esforço é mostrar como tal fraqueza representa "um obstáculo para a realização da vida".

Nietzsche o faz "introduzindo o termo "ressentiment", que é compreendido como "a revolta escrava na moral cristã", como uma "transição do bom para o mau, do bem para o mal na moral": o primeiro par (bom-mau) é reconhecido por Jonas como um "juízo qualitativo" de tipo aristocrático; o segundo (bem-mal) é um "juízo moral”, o qual implica uma atitude de medo, uma espécie de "reação repugnante em relação ao mal", um desejo de que ele não esteja lá. Sendo assim, "o mal deve ser erradicado, enquanto a maldade é algo meramente a ser evitada" (HJ, 202-6). O problema é que a força se revela justamente na disposição do enfrentamento daquilo que gera medo, ou seja, daquilo que enfraquece o homem. E isso passa necessariamente pela capacidade de deixar de lado as ilusões, para que a "verdade" seja enfrentada não apenas no que ela tem de prazer ou alívio. A verdade, para o homem, é "pensar sob a nudez de sua própria situação", sem apelo à ilusão de um Deus protetor, ou seja, é preciso "despir a realidade de todos os valores transcendentais" e "enfrentar esse nada como um homem [capaz de] criar seus próprios valores". Por isso, a coragem requerida é aquela que leva até o niilismo como ato de criação dos próprios valores: "isso é força para Nietzsche - a maneira segundo a qual a realidade é enfrentada sem qualquer véu de consolo e com o orgulho que desdenha igualmente dos adereços da fé e do desespero da falta de fé". Por isso, o conhecimento passa, em Nietzsche, pela ideia de "honestidade intelectual" (ou "probidade" [intellektuelle Redlichkeit] ou retidão intelectual) compreendida como a capacidade de um pensador regular as forças que estão em atividade nele, forças suficientes para orientá-lo em direção à verdade que reside no rompimento com as antigas ilusões, para além dos confortos psicológicos oferecidos pela religião. E isso é, afinal, para Nietzsche, um tema moral por excelência, na medida em que ele está conectado à capacidade de afirmação da vida por parte de um indivíduo ou de uma cultura. É por isso que, para Jonas, a remoção da ignorância proposta por Nietzsche, torna-se um assunto tão importante e um "aspecto muito sinistro", porque dela depende a possibilidade da vida.

Não se trata, contudo, de remover a ignorância como tal (já que essa é, paradoxalmente, algo útil para a vida), mas a ignorância que impede o reconhecimento da própria ignorância e que, 
afinal, se revela como verdade absoluta ou como crença nela e cujo ápice é a ideia de Deus. O erro está em negar que os valores são criados a partir do homem, das necessidades humanas, da natureza presente dos fatos: "a crise decisiva consiste em descobrir que os valores não são parte da natureza objetiva das coisas, mas projeções das preferências humanas na natureza das coisas". Ora, para Jonas, é “esse o sentido mais amplo de 'Deus está morto', isto é, os valores não são transcendentais, mas feitos pelo homem (man-made)". O valor desses valores não é negado por Nietzsche. Jonas se pergunta, contudo, "o que acontece com esses valores" e afirma que "a primeira relação é o niilismo", ou seja, os valores se articulam agora em torno dessa tentativa nietzschiana de olhar por trás deles, sob a perspectiva de que Deus deve ser entendido como uma invenção psicológica dos homens (algo que, afinal, causa um “colapso nos valores universais”).

\section{O eterno retorno como mais alta forma de desespero}

Ora, a morte de Deus é, assim, a condição para a intensificação do medo e, sendo assim, para a superação da ilusão trazida pela religião. Intensificar o desespero é, ao mesmo tempo, assumir a morte de Deus como fato e, diante dele, assumir a tarefa de autoafirmação. A solidão é, por isso, uma virtude moral essencial da nova atitude existencial do homem diante da ausência da ilusão redentora representada pela antiga divindade ${ }^{6}$. Nessa perspectiva, a morte de Deus é interpretada por Jonas como uma anulação da ideia de eternidade, em nome da temporalidade, afirmada pelo conceito de futuro como eterno retorno, interpretado como "autoafirmação", mas, sobretudo, como "autorrealização": "Deus está morto, então esta existência eterna não faz mais sentido, a única coisa que existe é temporal e o que está vivo”, ou seja, o que está fechado na “autorrealização da existência finita” (HJ, 20-2-1). A única eternidade admissível, nesse caso, é a redundância, ou seja, a "infinidade de combinações da realidade", que afirma sempre de novo a recorrência de todas as coisas: "Em um futuro incomensurável, eu quero estar aqui de novo e quero viver meu destino. Essa é a única eternidade à qual Nietzsche pode dizer sim”. Ou seja, a única possibilidade de afirmar a eternidade reside nessa afirmação radical da existência como "absoluta auto-performance, completada em si mesma", ou seja, vivenciada por cada indivíduo por meio da afirmação de suas próprias vivências. Jonas considera essa posição como a última forma do amor fati, revivida agora por Nietzsche, tal como antes esse conceito havia aparecido nos estoicos e em Spinoza. Amar o destino significa, precisamente, alcançar a "afirmação de mim mesmo, não de algo maior do que eu sou, mas de uma parte da inescapável diminuição da minha própria existência. Trata-se, assim, do "amor da vida completamente (utterly) niilístico, que eleva a si mesmo sobre o abismo e anda sobre ele sem propósito ou sem ser confortado por esperanças ou guiado por estrelas espirituais". E, ademais, essa é a afirmação completa da existência: "aqui eu estou, e eu preciso nadar. Diante de mim se abre a perspectiva segundo a qual eu devo nadar 
de novo em uma eternidade com o mesmo desesperado gesto. Essa é a canção do amor que ninguém canta" e essa é a ideia que Nietzsche tem de felicidade, ou seja, aquela que passa pela afirmação do próprio poder - um poder que não se exerce "sobre pessoas ou sobre coisas", mas sobre si mesmo, na forma de uma "consciência (awareness) do poder da vida de atuar, produzir e crescer". Dado que todos os valores espirituais foram esvaziados, Jonas insiste no fato de que "a mais alta forma de desespero da autoafirmação é refletida no eterno-retorno", como aquilo que, afinal, "toma o lugar da antiga ideia de um espaço ocupado pela alma eterna", embora Nietzsche saiba que a recorrência, nesse caso, não passe de uma postulação antecipada do que poderá acontecer sempre de novo. É como postulação que Jonas entende a teoria nietzschiana de eternoretorno: tal conceito está ligado diretamente à ideia de temporalidade como aquilo que acontece aqui e agora sobre o que todas as coisas estão assentadas. A eternidade é uma experiência do presente, portanto, da recorrência do amor que aceita radicalmente a temporalidade e torna possível a recorrência. Jonas capta, assim, de forma lúcida a nova perspectiva de valor instalada por Nietzsche: "Chegará a época na qual a diferença não será mais entre bom e mau, mas entre forte e fraco". E é essa escolha que o homem deve fazer para superar o seu medo: escolher a força significa escolher agir segundo a vontade de poder. Ele deve escolher a força: "o forte é aquele que é completamente mestre de si mesmo, um verdadeiro espírito livre tomando sobre si mesmo o fardo de ser orientado somente por si e não guiado por nada extrínseco a si mesmo que ele aceite como valorável”.

Jonas, contudo, não deixa de destacar que Nietzsche interpreta a inversão dos valores promovida pelos fracos como parte de seu próprio exercício de poder: "o real refinamento é que isso era uma expressão da vontade de poder, esta humildade tinha seu próprio caminho sutil para ganhar o poder. Então a criação e a aniquilação de valores é uma função da vontade de poder" (HJ, 20-2-2). O exercício da criação e da negação dos valores é, por si mesmo, a prova da ausência de valores absolutos e a afirmação da capacidade de interpretação do bem e do mal como medidas perspectivas de criação de valores. Assim, a ideia da "morte de Deus" é assumida não apenas como a morte do deus cristão, mas como um gesto de autoafirmação diante do "novo vitalismo do homem moderno e do niilismo completamente naturalístico" que obriga o homem a ver a si mesmo como o "criador (maker) dos valores e de sua própria vida". Esse seria, ao mesmo tempo, o "desespero e a esperança do homem", o seu "aspecto jubiloso e terrível", que o obriga a negar toda a transcendência em nome da temporalidade de sua condição.

Na sua perspectiva de interpretação do niilismo, Jonas considera a posição de Nietzsche, nesses termos, como um subjetivismo de tipo radical: "o subjetivismo de Nietzsche é total (utter) radicalismo, não sofisticação", na medida em que o homem decide, a cada momento o que quer ser e é a partir dessa decisão que ele pode criar a sua própria verdade. Aliás, Jonas não deixa de notar que "nós raramente encontramos a palavra 'verdade' em Nietzsche" (pelo menos em sentido 
positivo); no seu lugar ele fala de "honestidade intelectual", uma escolha que Jonas debita justamente ao subjetivismo nietzschiano: "não se iluda a si mesmo" seria o sentido próprio dessa escolha, ou seja, na busca pela verdade, cabe ao homem manter-se fiel unicamente a si. Ora, Jonas identifica essa posição como típica do existencialismo moderno, que é um "estágio histórico na história do pensamento" que transforma "a existência do homem no campo de batalha entre verdade ou mentira, bom ou mau etc. e também o seu lugar de nascimento". Em outras palavras: com Nietzsche instala-se a concepção filosófica segundo a qual é a existência (e não as realidades suprassensíveis) que serve de horizonte para a avaliação dos valores e é nela que nascem os conceitos, mesmo aqueles considerados como os mais "puros", "fixos" e "absolutos", tal como Nietzsche mesmo mostrou, especialmente em Humano, demasiado humano, ao afirmar que todos os conceitos têm história $(H H, 1)$. É nesse sentido que Jonas identifica o existencialismo moderno (que, nesse caso, inclui a filosofia nietzschiana) como uma espécie de antiplatonismo ou, pelo menos, como uma "abdicação do platonismo" em nome da afirmação da existência, ela mesma considerada como o campo de interesses sobre os quais os valores eternos são gerados e mantidos. É isso o que faz Jonas afirmar que "essa perspectiva foi visualizada por Nietzsche com maior clareza do que qualquer outro pensador moderno". Em contraste com Epicuro, "ele não desenhou uma vida fácil”.

\section{O sentido naturalista da solidão e a vontade de poder}

Eis a novidade na "interpretação do homem" por parte de Pascal e Nietzsche em comparação com o mundo clássico: no sentido moderno dessa interpretação, a ideia de um "homem sozinho" tem sido largamente explorada. Um dos tópicos tratados por Jonas em seu curso em Ottawa, tem como título precisamente essa questão antropológica: “Auto-interpretação humana nessa atmosfera ateísta", no qual ele analisa dois aspectos da solidão humana:

1. O homem é radicalmente diferente do resto da natureza: ele não tem organicamente um nicho na natureza ao qual ele pertence e pelo qual seu pertencimento possa dar a ele um senso de integração. Esse harmonioso conceito de homem foi quebrado devido a uma longa história de proximidade com o dualismo. Portanto, esse foi um desenvolvimento de tipo religioso.

2. O dictum (máxima) pode também significar que não há Deus cuja relação com o homem (ou vice-versa) poderia superar o estranhamento do homem em relação à natureza. Essa última possibilidade é a única que a religião gnóstica $\mathrm{e}$ a cristã imaginaram quando elas quebraram a ideia do pertencimento do homem à natureza, o homem foi deixado como um estrangeiro no mundo e ele pertence a uma outra ordem. Uma dupla solidão ocorreria caso o homem fosse privado também de Deus. Essa é a situação colocada por Nietzsche, não como um retorno à piedade natural pagã, mas um degrau abaixo nessa direção (further down on the road). (HJ, 20-2-2; sublinhado do autor) 
Isso significa que a religião aparece, como denunciara Nietzsche, como uma oferta de segurança diante da solidão representa pelo rompimento entre homem e mundo; ou seja, para evitar o colapso completo da condição humana, por ela inaugurada com a ascensão do dualismo homem-mundo, a religião (gnóstica e cristã, note-se bem) teria mantido a ideia de pertencimento do homem a uma "outra ordem", ou seja, à ordem divina. É justamente para combater esse engano que a filosofia de Nietzsche teria se apresentado como uma tentativa de radicalizar a condição solitária do homem, considerada por ele como uma espécie de remédio que não cura. É por isso que Jonas escreve: "se o niilismo de Nietzsche é primeiramente o niilismo criado pela rejeição da ordem espiritual, então é inevitável que reste apenas a natureza como a realidade com a qual o homem tem de lidar" (HJ, 20-2-2). Jonas considera, assim, que Nietzsche "troca a ordem espiritual por um muito franco e quase cru naturalismo", no qual o homem não está em interligação com a natureza, mas, ao contrário, diante da qual ele encontra-se sozinho. Essa ideia de natureza está ligada a uma concepção de "natureza de forças", ou seja, não uma natureza ordenada hierarquicamente segundo o modelo do antigo cosmos, "mas uma natureza que é essencialmente o cenário de forças interativas", aos moldes do que Nietzsche compreende como vontade de poder. Ora, como o homem é interpretado em um "sentido naturalista", afirma Jonas, então "a essência do homem deve ser uma força que é representada por sua vontade consciente", ou seja, a sua "essência" é algo que, por si mesmo, distancia-se totalmente da antiga ideia de essência, já que agora não se concebe mais uma qualidade ou uma estrutura prévia ou fixa para o homem - ele é apenas um campo para o jogo de forças que constituem a natureza como um todo.

Para Jonas, o "objeto da vontade é o objeto de todas as forças, o exercer a si mesmo, a vontade é a vontade de poder". Com essa afirmação, Jonas chega a uma questão primordial: no exercício das forças, a vontade não tem como objeto (e, consequentemente, nem o homem como seu objetivo) as coisas mesmas, ou seja, os seres que formam o mundo ao seu redor, mas simplesmente colocar em prática aquela que se tornou a característica central do homem moderno, ou seja, o seu poder. É por isso que, para Jonas, se antigamente a definição de homem era algo como "homem é um animal racional", o niilismo moderno apresenta uma nova perspectiva: "homem é vontade de poder", ou seja, exercício de força, resultado provisório das sempre novas agregações de sentido doadas pelas forças em constante conflito entre si. Nessa interpretação, Jonas já pensa o poder como atividade técnica do homem: “o objetivo não é ajustar (to fit) o esquema das coisas, mas realizar ao máximo o seu próprio poder, ser o criador da natureza". Por isso, "o homem, como o fazedor, é a única escolha possível se o homem como criatura na perspectiva total da natureza não é mais a visão do homem”. Jonas é muito claro a esse respeito: em tal situação de fazedor, o homem não é mais o ser racional, porque a razão tem como objeto o ser das coisas, ou seja, como uma possibilidade de acesso àquilo que as coisas são em si mesmas, ela já não ocupa mais nenhum lugar na lógica da descrição da vontade de poder - da qual, em 
último caso, ela continua apenas servindo como uma espécie de instrumento, como é o caso da ligação moderna entre saber e poder. Se no passado cabia à razão a contemplação da ordem perfeita, ou seja, das ideias imutáveis e à maior das nobrezas, que era a ausência de movimento, agora a ideia de força e de vontade de poder inverte essa perspectiva. O ser já não se apresenta mais na sua fixidez, mas justamente no seu oposto, no movimento, no tornar-se. Jonas apela para Lessing (que ele chama de "o mais friamente sóbrio e totalmente analítico de todos os pensadores alemães" [HJ 20-2-2]) para mostrar que a perspectiva do niilismo moderno dá preferência para o movimento, ou seja, para o processo: "o processo como tal, a atividade como o sentimento do próprio poder, não como a tendência a alcançar certo objetivo para, então, descansar, mas para sua própria causa". Em outras palavras: a experiência do poder como abertura de possibilidades é preferível à posse de algum tipo de objeto último diante do qual a faculdade do poder encontrarse-ia em estado de repouso. Alcançar um objeto é, já, anular a expressão do poder; por isso, é melhor não escolher nenhum objetivo que não seja o próprio exercício da força como tal, ou seja, o próprio exercício do poder. Sem um objetivo fora de si mesma, a vontade de poder torna a mente moderna "subjetiva e autocentrada" de uma maneira inédita na história do pensamento e faz da vontade técnica, como veremos mais adiante, uma vontade de poder atirada unicamente a si própria, nos moldes do que Jonas chama de "dinâmica formal” (TME, 25).

\section{Conclusão: sobre como enfrentar o niilismo é radicalizá-lo}

Para Jonas, contudo, "a queda no niilismo não é o descanso do pensador corajoso", pois ele quer ir além: "o niilismo deve ser enfrentado e ultrapassado (faced and passed through) em um primeiro estágio", ou seja, o pensador deve ir além do niilismo, ele quer saber "como ir além do niilismo" e isso só pode ser alcançado através da tomada de consciência de que o próprio homem é o criador de Deus e dos valores, o que passa pela aceitação da "insuportável solidão do pensador" que recusa ser enganado e protegido. Uma vez tendo se dado conta de sua situação, o pensador não pode retornar ao "estágio pré-niilista": "uma vez a luz é acesa ela não pode ser desligada novamente", ou seja, não há mais escolha a não ser ir além, ir até o final, até aquilo que, na linguagem nietzschiana se chama superação do niilismo e que ocorre por meio de sua intensificação. Eis que a "honestidade intelectual" se apresenta como renúncia ao recuo à antiga intimidade do pensamento: agora que o niilismo foi pensado como fenômeno, não há outra saída a não ser levá-lo adiante, ou viver na tentativa de superá-lo, embora tal tarefa seja bastante grandiosa para qualquer filosofia. Esse é o tipo de orgulho nascido do exercício das forças, uma espécie de egoísmo ("interesse do eu”) advindo do colapso dos valores objetivos, que conduz à afirmação do eu como possibilidade de existência e como enfrentamento do niilismo. Uma pessoa dessas, afirma Jonas, em tom nietzschiano, "escolherá fazer da vida sua própria criação definindo 
seus padrões de acordo com os quais pode-se viver mais - independência aristocrática" (HJ, 202-6). É assim que o espírito livre pode alcançar sua própria liberdade: "um conjunto de valores aristocráticos escolhidos com o conhecimento pleno de que eles são escolhas arbitrárias". É nessa escolha de valores aristocráticos, portanto, que se torna possível "a volta (twist) que leva para fora do niilismo sem remeter de volta para o pré-niilismo", ou seja, sem que se retorne à antiga crença nos valores absolutos.

Assim, para Jonas, se o niilismo não pode ser superado, seu enfrentamento depende dessa atitude corajosa que não deseja o retorno à situação anterior, mas um recuo até onde o homem possa assumir o niilismo como necessário para a afirmação da vida. Por isso, para Jonas, "o homem que vive sua vida como um jogo supremo com pleno conhecimento de que todos os objetivos que ele define são objetivos de sua própria escolha e, portanto, ele está em condições de quebrá-los a qualquer momento" é aquele que se torna mais digno: "combinando a dignidade dos valores pré-niilistas com o secreto conhecimento de sua relatividade -dignidade seguida da decisão voluntária do indivíduo em viver neles como a lei e ainda saber de sua relatividade -isso é o caminho para fora do niilismo". Em outras palavras, "os valores se tornam ainda mais nobres" quando se tem consciência de sua raiz relativa e, nesse sentido, o novo ascetismo se coloca "a serviço do orgulho".

Dessa forma, Nietzsche preserva a ideia do homem em sua "existência única" no universo, na medida em que o reconhece como o ser habilitado a projetar, a partir de si mesmo, valores capazes de transformá-lo em um superman, "ou seja, "mais mentalmente avançado e espiritualmente soberano do que o homem do presente". Isso significa que o Übermensch nietzschiano está longe daquele imaginado pelos pós-humanistas ou transumanistas contemporâneos, na medida em que sua força não reside na capacidade de melhoria tecnológica de si mesmo, mas na superação das antigas dependências ilusórias, resumidas na ideia da morte de Deus. Ora, se reconhecermos que a utopia tecnológica continua a oferecer uma espécie de dependência e de narcótico para a solidão e o medo do homem diante do mundo, então o homem tecnológico não passaria de mais uma tentativa de recuo ao pré-niilismo - e não de seu enfrentamento, como veremos mais adiante. Jonas não deixa de notar que uma atitude como essa, proposta por Nietzsche, não é para muitos e nem pode ser desejada a não ser por uns poucos, pois depende de uma rara "nobreza intelectual": por isso "novos escritores de valores terão em vez de crença, vontade", ou seja, usarão esse conhecimento (no limite, um "supremamente arbitrário elemento") e sua tarefa será criar uma nova "imagem" da humanidade, criada a partir da "escolha aristocrática". É assim que "o homem deve colocar a si mesmo no lugar de Deus" e, por meio desse experimento, "Nietzsche pretende assumir a posição na qual o niilismo foi deixado situação onde a filosofia não precisa mais acreditar em um mundo ou em forças transcendentais", 
pois "não há mais nenhuma possibilidade de crença honesta em outro mundo", a não ser afirmar o mundo imanente, no qual o homem é orientado pelas suas próprias escolhas. 


\section{Notas}

${ }^{1}$ Professor do Programa de Pós-graduação em Filosofia da Pontifícia Universidade Católica do Paraná (PUCPR), Curitiba, P. R., Brasil. E-mail: jelsono@yahoo.com.br

O presente artigo é fruto do estágio de pós-doutoramento realizado na Universidade de Exeter, no Reino Unido, com apoio da CAPES (Coordenação de Aperfeiçoamento de Pessoal do Ensino Superior), processo BEX 6115/15-2.

2 Jonas defendeu sua tese doutoral Der Begriff der Gnosis em 1928, sob a orientação de Heidegger; o texto foi parcialmente publicado em 1930 (Der Begriff der Gnosis. Inaugural-Dissertation zur Erlangung der Doktorwürde der Hohen Philosophischen Fakultät der Philipps-Universität zu Marburg, Hubert \& Co., Göttingen, 1930) e assumido como parte da obra definitiva publicada postumamente em 1993 (597-667 e 675-680 da edição italiana que consta nas referências). Em 1934, é publicado Gnosis und spätantiker Geist. Erster Teil: Die mythologische Gnosis (reimpresso em 1954, 1964 e 1988) ao qual deveria seguir, imediatamente, um segundo volume, já parcialmente escrito pelo autor, projeto que fora interrompido pelo advento da II Guerra Mundial. Gnosis und spätantiker Geist. Teil II, 1: Von der Mythologie zur mystischen Philosophie, só seria publicado em 1954 (reimpresso em 1966 e 1993). Em 1958, já na New School os Social Research, Jonas publicou uma versão abreviada do texto, de caráter mais "divulgativo", intitulada The Gnostic Religion. The message of the Alien God and the Beginnings of Christianity. Esse texto abrevia a fundamentação filosófica da obra maior e concentra-se basicamente sobre a gnose mitológica, tratando apenas de forma breve a transformação místico-filosófica da gnose, presente na segunda parte e nos textos posteriores, sobre Plotino. Mas, no geral, ele mantém a mesma linha argumentativa dos trabalhos anteriores, somada a uma maior precaução em relação ao uso da interpretação existencial heideggeriana. Em 1967, Jonas escreve o verbete sobre Gnosticism para a Encyclopedia of Philosophy, texto que guarda similaridades com outro texto do mesmo ano, intitulado Delimitation of the Gnostic Phenomenon: Typological and Historical (publicado por Ugo Bianchi em Le origini dello gnosticismo [Leiden, E. J. Brill, p. 90-108] e reeditado como o capítulo treze dos Philosophical Essays, de 1974, cujo título é The Gnostic Syndrome. Typology of its Thought, Imagination, and Mood. Essa publicação é resultado da Conferência sobre as origens do Gnosticismo, organizada por Ugo Bianchi em Messina, entre os dias 13 e 18 de abril de 1966, com a participação de iminentes especialistas no assunto, entre os quais, além do próprio Jonas, estavam J. Ries, G. Gnoli, G. Quispel e Kurt Rudolph. Uma das principais discussões desse evento foi a distinção da definição do termo gnosticismo em relação a gnose ( $c f$. SMITH, Norton, The History of the term gnostikos, 1996, esp. p. 183-189). Em 1993, uma versão definitiva do trabalho inicial de Jonas foi publicada sob coordenação de Kurt Rudolph, na qual foram acrescentados os textos sobre Plotino que Jonas havia escrito de forma esparsa, mas desde muito cedo indicado como parte fundamental da discussão sobre a passagem da mitologia à filosofia mística. Apesar de ter acompanhado a organização e edição desses textos na nova versão da obra, Jonas faleceu às vésperas de sua publicação.

${ }^{3}$ No presente artigo usaremos as siglas convencionais para a citação das obras de Hans Jonas: TME (Técnica, Medicina e Ética); RG (A Religião Gnóstica: A mensagem do Deus estranho e os começos do cristianismo). Seguindo a sigla referente ao título da obra, está o número da página. Para a referência do manuscrito inédito intitulado The theory of God, usaremos as siglas referentes aos documentos conservados no Arquivo Hans Jonas, de Konstanz, na forma HJ 20-2-1 (na seguinte ordem: sigla do arquivo Hans Jonas; número da caixa, número da pasta e número do documento). Para a obra de Nietzsche usaremos as siglas: GC (A Gaia Ciência), HH (Humano, demasiado humano); ZA (Assim Falou Zaratustra).

${ }^{4}$ Tratamos desse aspecto da obra de Nietzsche no artigo "Ascetismo e inocência: a questão da religião no Humano, demasiado humano de Nietzsche” (OLIVEIRA, 2017).

\footnotetext{
${ }^{5}$ Tal como aparece em $O$ Anticristo (aforismo 12); Assim Falou Zaratustra (Dos Transmundos), A Gaia Ciência (aforismo 335) ou, na perspectiva do "rigoroso método da verdade", em Humano, demasiado humano (HH, 109). Com seu argumento, Jonas antecipa, a seu modo, aquilo que Werner Stegmaier considera como sendo a "virtude filosófica por excelência" (STEGMAIER, 2013, p. 137) anunciada pela filosofia de Nietzsche.

${ }^{6}$ Em trabalho anterior, tematizamos o sentido da solidão no pensamento de Nietzsche ( $c f$. OLIVEIRA, 2010).
} 


\section{Referências}

EPICURO. Antologia de textos. Traduções e notas de Agostinho da Silva ... [et al.]; Estudos introdutórios de E. Joyau e G. Ribbeck. 3. ed. São Paulo: Abril Cultural, 1985. (Col. Os Pensadores).

FROGNEUX, Nathalie. Hans Jonas ou la vie dans le monde. Bruxelles: De Boeck Université, 2001. (Col. Le Point Philosophique).

JONAS, Hans. Gnosi e spirit tardoantico. Introduzione, traduzione, note e apparati di Claudio Bonaldi. Milano: Bompiani, 2010 (Col. Il Pensiero Occidentale).

JONAS, Hans. La religión gnóstica: El mensage del Dios Extraño y los comienzos del cristianismo. Prólogo de José Montserrat Torrents; Traducción de Menchu Guiérrez. Madrid: Ediciones Siruela, 2000.

JONAS, Hans. Philosophical Essays. From ancient creed to technological man. New York: Atropos Press, 2010.

JONAS, Hans. Técnica, medicina e ética. Sobre a prática do princípio responsabilidade. Trad. Grupo de Trabalho Hans Jonas da ANPOF. São Paulo: Paulus, 2013. (Col. Ethos).

JONAS, Hans. Theory of God. Inéditos do Philosophisches Archiv de Hans Jonas, na Universität Konstanz. Konstanz: 2017.

OLIVEIRA, Jelson. Ascetismo e inocência: a questão da religião no Humano, demasiado humano de Nietzsche. Cadernos Nietzsche, São Paulo, n. 33, p. 215-244, 2013. Disponível em: < https://goo.gl/iCIK39>. Acesso em: 24 Jan. 2017.

OLIVEIRA, Jelson. A solidão como virtude moral em Nietzsche. Curitiba: Champagnat, 2010. (Col. Pensamento contemporâneo, 5).

SMITH, Norton. The history of the term gnostikos. In: Studies in the Cult of Yahweh 2, New Testament, Early Christianity, \& Magic. Ed. by Shaye J. D. Cohen. Leiden: E. J. Brill, 1996.

STEGMAIER, W. As linhas fundamentais do pensamento de Nietzsche. Trad. André Luis M. Garcia; Oswaldo Giacóia Jr. et. al. Petrópolis: Vozes, 2013. 